\title{
The Potent BACE1 Inhibitor LY2886721 Elicits Robust Central A $\beta$ Pharmacodynamic Responses in Mice, Dogs, and Humans
}

\author{
Patrick C. May, ${ }^{1}$ Brian A. Willis, ${ }^{1}$ Stephen L. Lowe, ${ }^{2}$ Robert A. Dean, ${ }^{1}$ Scott A. Monk, ${ }^{1}$ Patrick J. Cocke, ${ }^{1}$ \\ D'James E. Audia, ${ }^{1}$ Leonard N. Boggs, ${ }^{1}$ Anthony R. Borders, ${ }^{1}$ Richard A. Brier, ${ }^{1}$ David 0. Calligaro,,${ }^{1}$ Theresa A. Day, ${ }^{1}$ \\ Larry Ereshefsky, ${ }^{3 *}$ Jon A. Erickson, ${ }^{1}{ }^{\circ}$ Hykop Gevorkyan, ${ }^{4}$ Celedon R. Gonzales, ${ }^{1}$ Douglas E. James, ${ }^{1}$ Stanford S. Jhee, ${ }^{3}$ \\ Steven F. Komjathy, ${ }^{1}$ Linglin Li, ${ }^{1}$ Terry D. Lindstrom, ${ }^{1} \dagger$ Brian M. Mathes, ${ }^{1}$ Ferenc Martényi, ${ }^{1}$ Scott M. Sheehan, ${ }^{1}$ \\ Stephanie L. Stout, ${ }^{1}$ David E. Timm, ${ }^{1}$ Grant M. Vaught, ${ }^{1}$ Brian M. Watson, ${ }^{1}$ Leonard L. Winneroski, ${ }^{1}$ Zhixiang Yang, ${ }^{1}$ \\ and ${ }^{\circ D}$ Dustin J. Mergott ${ }^{1}$ \\ ${ }^{1}$ Lilly Research Laboratories, Eli Lilly and Company, Indianapolis, Indiana 46285, ${ }^{2}$ National University of Singapore Centre for Clinical \\ Pharmacology, Singapore 117597, Singapore, ${ }^{3}$ PAREXEL International, Glendale, California 91206, and ${ }^{4}$ California Clinical Trials Medical Group, \\ Inc., Glendale, California 91206
}

BACE1 is a key protease controlling the formation of amyloid $\beta$, a peptide hypothesized to play a significant role in the pathogenesis of Alzheimer's disease (AD). Therefore, the development of potent and selective inhibitors of BACE1 has been a focus of many drug discovery efforts in academia and industry. Herein, we report the nonclinical and early clinical development of LY2886721, a BACE1 active site inhibitor that reached phase 2 clinical trials in AD. LY2886721 has high selectivity against key off-target proteases, which efficiently translates in vitro activity into robust in vivo amyloid $\beta$ lowering in nonclinical animal models. Similar potent and persistent amyloid $\beta$ lowering was observed in plasma and lumbar CSF when single and multiple doses of LY2886721 were administered to healthy human subjects. Collectively, these data add support for BACE1 inhibition as an effective means of amyloid lowering and as an attractive target for potential disease modification therapy in AD.

Key words: Alzheimer's disease; amyloid beta; BACE1; clinical trial; nonclinical animal model

\section{Introduction}

Alzheimer's disease $(\mathrm{AD})$ is an age-related, neurodegenerative disorder characterized by progressive memory loss ultimately

\footnotetext{
Received Oct. 1, 2014; revised Nov. 19, 2014; accepted Nov. 27, 2014.

Author contributions: P.C.M., B. Willis, S.L., R.D., J.A., D.C., J.E., F.M., G.V., B. Watson, L.W., and D.M. designed research;P.C.M., B. Willis, R.D., S.M., L.B., A.B., R.B., T.D., L.E., H.G., S.J., L.L., S. Stout, D.E.T., Z.Y., and D.M. performed research;S.M. contributed unpublished reagents/analytic tools; P.C.M., B. Willis, S.L., R.D., S.M., P.C., J.A., L.B., A.B., R.B., D.C., L.E., H.G., C.G., D.J., S.J., S.K., L.L., T.L., B.M., F.M., S. Sheehan, S. Stout, D.E.T., G.V., B. Watson, L.W., Z.Y., and D.M. analyzed data; P.C.M., B. Willis, S.L., R.D., S.M., P.C., J.A., L.B., A.B., R.B., D.C., T.D., L.E., J.E., H.G., C.G., D.J., S.J., S.K., L.L., T.L., B.M., F.M., S. Sheehan, S. Stout, D.E.T., G.V., B. Watson, L.W., Z.Y., and D.M. wrote the paper.

This work was funded by Eli Lilly and Company. The Advanced Photon Source, an Office of Science User Facility operated for the U.S. Department of Energy (DOE) Office of Science by Argonne National Laboratory, is supported by the U.S. DOE under Contract No. DE-AC02-06CH11357. Use of the Lilly Research Laboratories Collaborative Access Team (LRL-CAT) beamline at Sector 31 of the Advanced Photon Source was provided by Eli Lilly Company, which operates the facility. We thank Martin Citron for strategic input, D. Richard Lachno for analytical methods development, Elizabeth LaBell and Leslie Daugherty for clinical operations, Angela Murff-Maxey for project management, and Tamara Ball for assistance with the technical writing of this manuscript.

Dr. Ball is a scientific writer employed by inVentiv Clinical, a CRO contracted by Eli Lilly and Company (Lilly) for the technical writing of this manuscript. P.C.M., B.A.W., S.L.L., R.A.D., S.A.M., P.J.C., L.N.B., A.R.B., R.A.B., D.O.C., T.A.D., J.A.E., C.R.G., D.E.J., S.F.K., L.L., B.M.M., S.M.S., S.L.S., D.E.T., G.M.V., B.M.W., L.L.W., Z.Y., and D.J.M. are all employed by and minor stockholders in Lilly. T.D.L. was formerly an employee of and is presently a minor stockholder in Lilly. H.G. is employed by California Clinical Trials Medical Group, Inc., and L.E. and S.S.J. are employed by PAREXEL, both of which are CROs contracted by Lilly to conduct the phase 1 studies. J.E.A. and F.M. are former employees of Lilly. J.E.A. is employed by Constellation Pharmaceuticals and is a minor stockholder in Lilly. F.M. is employed by Takeda Pharmaceuticals.

*Retired (formerly Professor of Psychiatry, Pharmacology, and Pharmacy at The University of Texas at Austin, 78705).

tRetired.
}

leading to dementia. Neuropathologic hallmarks of AD include the accumulation of extracellular amyloid plaques, intracellular neurofibrillary tangles, and neuronal loss in specific brain regions such as the hippocampus and cerebral cortex, which are important for cognition, learning, and memory. Amyloid $\beta(\mathrm{A} \beta)$ plaques consist primarily of assemblies of a small 39-43 aa peptide arising from the cleavage of APP. The amyloidogenic processing of APP is initiated by BACE1 (also known as $\beta$-secretase), an aspartyl protease that was cloned by several groups including Sinha et al. (1999) and Vassar et al. (1999). One of the familial forms of AD is caused by a double mutation, $\mathrm{KM} \rightarrow \mathrm{NL}$, at amino acids immediately adjacent to the BACE1 cleavage site (Mullan et al., 1992). Kinetic assays with recombinant BACE1 demonstrate a significantly higher activity of BACE1 against this so-called Swedish mutated APP compared with wild-type residues at that site (Sinha et al., 1999; Vassar et al., 1999), so this "gain-of-function" mutation in APP is associated with an early onset familial form of AD. Conversely, a "loss-of-function" mutation in APP has recently been described in an Icelandic kindred in which an A673T poly-

Correspondence should be addressed to Dustin J. Mergott, Lilly Research Laboratories, Eli Lilly and Company, 893 S. Delaware Street, Indianapolis, IN 46225. E-mail: mergott_dustin_james@lilly.com.

J.E. Audia's present address: Constellation Pharmaceuticals, Cambridge, MA 02142.

F. Martényi's present address: Takeda Pharmaceuticals, Deerfield, IL 60015.

DOI:10.1523/JNEUROSCI.4129-14.2015

Copyright $\odot 2015$ the authors $\quad 0270-6474 / 15 / 351199-12 \$ 15.00 / 0$ 
morphism in APP has been associated with reduced $\mathrm{A} \beta$ production and apparent protection against $\mathrm{AD}$ and cognitive decline with aging (Jonsson et al., 2012). These genetic data offer strong support for BACE1 as a key mediator of amyloid-driven pathology. Moreover, these findings suggest that brain penetrant BACE1 inhibitors under development may be able to delay the progression of $\mathrm{AD}$ by reducing the extent of amyloid formation. BACE1 knock-out $(\mathrm{KO})$ mice are viable and fertile and initially were reported to be without a major phenotype (Cai et al., 2001; Luo et al., 2001; Roberds et al., 2001). Although more recent characterization of BACE1 KOs has revealed selected morphologic and functional deficits in these animals (for review, see Vassar et al., 2014) and has introduced a level of caution, these findings have not limited enthusiasm for the development of BACE1 inhibitors. Overall, BACE1 has represented an attractive target for the pharmaceutical industry since its original discovery (Hussain et al., 1999; Sinha et al., 1999; Vassar et al., 1999; Yan et al., 1999; Lin et al., 2000). Early progress was slow due to challenges in translating potent enzymatic activity into productive BACE inhibition in central compartments in vivo. A significant breakthrough came in 2011 with the report of LY2811376, a moderately potent, drug-like BACE1 inhibitor that produced robust pharmacodynamics changes in nonclinical animal models and healthy volunteers (May et al., 2011). Although the clinical development of this molecule was discontinued due to nonclinical, off-target-related pathology, these data provided critical support for small-molecule intervention to test the amyloid hypothesis. Herein, we describe the nonclinical and early clinical development of LY2886721, a potent BACE1 inhibitor that reached phase 2 testing in patients with $\mathrm{AD}$.

\section{Materials and Methods}

\section{Preparation of LY2886721}

$\mathrm{N}$-(3-((4aS,7aS)-2-Amino-4a,5,7,7a-tetrahydro-4H-furo[3,4-d][1,3]thiazin7a-yl)-4-fluorophenyl)-5-fluoropicolinamide (LY2886721) can be prepared as described in US Patent 8,278,411. All nonclinical studies were conducted with the hydrochloride salt of LY2886721 and all clinical studies were conducted using the free base form of LY2886721.

\section{Crystallography}

BACE1 crystals were prepared as described previously with minor modifications (Hong et al., 2000). Briefly, crystals were soaked with $2.5 \mathrm{~mm}$ compound and flash cooled in liquid nitrogen using glycerol as a cryoprotectant. X-ray diffraction data and BACE1 co-crystal structure was solved as described in May et al. (2011) (see Table 1 for crystallographic data).

\section{Recombinant BACE1 and BACE2 assays}

Human BACE1 and BACE2 enzyme assays were conducted essentially as described by May et al. (2011) using purified recombinant human BACE1 or BACE2 as an enzyme source and a synthetic fluorescence resonance energy transfer (FRET) peptide as a substrate.

\section{Aspartyl protease selectivity enzyme assays}

Cathepsin D, pepsin, and renin assays were conducted essentially as described by May et al. (2011) using commercially available reagents and assays. Human liver Cathepsin D was purchased from Calbiochem (catalog \#219041). Porcine gastric mucosa pepsin was purchased from Sigma (catalog \#P-6887). Recombinant human renin was purchased from AnaSpec (catalog \#72040). For all enzyme assays, a 10-point inhibition curve was plotted and fitted with a four-parameter logistic equation to obtain the $\mathrm{IC}_{50}$ values.

\section{Cell-based assays}

Activity of LY2886721 was evaluated in two different cell assays essentially as described in May et al. (2011) to assess potency against native BACE1 in a normal physiologic cellular membrane context. In one cell-
Table 1. Crystallographic data

\begin{tabular}{ll}
\hline Space group & $\mathrm{P}_{1} 2_{1} 2_{1}$ \\
\hline Cell constants & $86.43 \times 89.77 \times 130.66 \AA^{3}, \alpha=\beta=\gamma=90^{\circ}$ \\
Resolution & $73.99-1.77 \AA$ \\
Unique reflections & $99,735(14,421)$ \\
Completeness & $100 \%(100 \%)$ \\
Multiplicity & $7.3(7.3)$ \\
Rmerge & $0.097(0.469)$ \\
Mn (I/SD) & $13.2(3.9)$ \\
Rcryst & $0.173(0.230)$ \\
Rfree & $0.207(0.284)$ \\
RMSD bonds & $0.010 \AA$ \\
RMSD angles & $1.39 \mathrm{deg}$ \\
Mean B value & $19.35 \AA^{2}$ \\
\hline
\end{tabular}

$\mathrm{Mn}(\mathrm{I} / \mathrm{SD})$, Mean intensity divided by the mean SD; RMSD, root mean square deviation.

Crystallographic statistics are from REFMAC (Murshudov et al., 1997) and SCALA (Winn et al., 2011). Values for the highest-resolution shell $(1.86-1.77)$ are in parentheses.

based assay, a human embryonic kidney cell line (HEK293) stably expressing APP751cDNA containing a Swedish mutation (HEK293 ${ }_{\text {Swe }}$ ) was exposed to increasing concentrations of LY2886721 and the amount of amyloid $\beta_{1-40}\left(\mathrm{~A} \beta_{1-40}\right)$ and $\mathrm{A} \beta_{1-42}$ measured in the media as an index of BACE1 inhibition. Compound cytotoxicity was assessed using a CellTiter96 Aqueous Non-Radioactive Cell Proliferation assay from Promega (catalog \# G54530). In the second cell-based assay, primary cortical neurons prepared from embryonic day 16 PDAPP transgenic mouse embryos were exposed to increasing concentrations of LY2886721 and the amount of $\mathrm{A} \beta_{1-40}$ and $\mathrm{A} \beta_{1-42}$ measured in the media as an index of BACE1 inhibition. Compound cytotoxicity was assessed using the MTT cytotoxicity assay.

\section{PDAPP mouse in vivo pharmacology}

In vivo pharmacology studies were conducted in young PDAPP transgenic mice essentially as described by May et al. (2011). Young (2-3 months old) female hemizygous APP ${ }^{\mathrm{V} 717 \mathrm{~F}}$ transgenic mice (PDAPP) from Taconic (private line 6042T) were used in these studies. Typically, 32-40 mice were randomly assigned by parental lineage into groups of 6-8 mice. Studies included a control group administered a $10 \mathrm{ml} / \mathrm{kg}$ dose volume of vehicle (7\% Pharmasolve) by oral gavage and drug-treated groups receiving indicated doses of LY2886721 by oral gavage. At designated time points, mice were anesthetized with $\mathrm{CO}_{2}$ and killed by decapitation. Bilateral hippocampal and cortical brain regions were rapidly microdissected, frozen on dry ice, and stored at $-80^{\circ} \mathrm{C}$ until analysis. The remaining brain tissue was flash frozen and used for compound exposure assessment. For analysis of parenchymal A $\beta, \mathrm{C} 99$, and secreted amyloid precursor protein $\beta$ (sAPP $\beta$ ), brain samples were homogenized in $5.5 \mathrm{M}$ guanidine- $\mathrm{HCl}$ buffer and extracts were collected, diluted, and filtered before ELISA. The use of animals in these pharmacology studies conformed to the Institutional Animal Care and Use guidelines for Eli Lilly and Company.

\section{Beagle dog in vivo pharmacology}

Beagle dogs were used as a secondary in vivo pharmacology model to assess BACE1 inhibition in a nontransgenic animal model. Beagle dog pharmacology studies were conducted in a cannulated dog model established at MPI Research. In this model, beagle dogs were implanted with a cannula in the lumbar spine region and threaded up toward the cervical spine. This model allowed multiple CSF collections throughout a single $48 \mathrm{~h}$ study period. To assess central pharmacology of LY2886721, CSF was collected $0.5 \mathrm{~h}$ before dosing to establish a baseline in 6 male cannulated beagle dogs and then again at 3, 6, 9, 24, and $48 \mathrm{~h}$ after dosing a 1.5 $\mathrm{mg} / \mathrm{kg}$ dose of LY2886721 in a standard 10\% Acacia formulation by oral gavage. Blood samples were drawn at baseline and throughout the $48 \mathrm{~h}$ period to assess compound exposure and peripheral pharmacodynamic responses. Amyloid $\beta_{1-\mathrm{x}}\left(\mathrm{A} \beta_{1-\mathrm{x}}\right)$ levels were measured in CSF and plasma and averaged across all six animals, then plotted as a function of time relative to baseline. The use of animals in these pharmacology studies 
conformed to the Institutional Animal Care and Use guidelines for Eli Lilly and Company.

\section{$A \beta, C 99$, and sAPP $\beta$ ELISAs}

Various $\mathrm{A} \beta$ isoforms were measured in conditioned media from cells, mouse brain parenchymal homogenates, or beagle dog plasma and CSF as described in Dovey et al. (2001) and May et al. (2011). Briefly, A $\beta$ peptides starting at $\mathrm{A} \beta$ residue $1\left(\mathrm{~A} \beta_{1-\mathrm{x}}\right)$ were measured with a sandwich ELISA using monoclonal $\mathrm{m} 266.2$ as a capture antibody and biotinylated $3 \mathrm{D} 6$ (anti-A $\beta_{1-5}$ ) as a reporting antibody. Alternatively, $\mathrm{A} \beta_{1-40}$ and $\mathrm{A} \beta_{1-42}$ peptides were measured by a sandwich ELISA using monoclonal $2 \mathrm{G} 3$ as a capture antibody for $\mathrm{A} \beta_{1-40}$ and monoclonal $21 \mathrm{~F} 12$ as a capture antibody for $\mathrm{A} \beta_{1-42}$. Both $\mathrm{A} \beta_{1-40}$ and $\mathrm{A} \beta_{1-42}$ ELISAs used biotinylated 3 D6 as the reporting antibody. ELISA values were normalized to protein levels (determined in duplicate by the Bradford Coomassie Plus Protein method) and are expressed as pictograms per milligram of protein. C99 protein levels in brain homogenates were determined with a sandwich ELISA by using an anti-APP C-terminal antibody (catalog \#8717; Sigma) to capture the analyte and biotinylated anti-APP antibody (3D6) to detect the $\mathrm{N}$ terminus of $\mathrm{C} 99$. Parenchymal C99 levels were normalized to protein levels as with $\mathrm{A} \beta$ (above) and expressed as nanograms per milligram of protein. SAPP $\beta$ protein levels in brain homogenates were determined with a sandwich ELISA using an anti-APP antibody (8E5) to capture the analyte, anti-neo-epitope antibody (GN2114 rabbit polyclonal) to bind the $\mathrm{C}$ terminus of the sAPP $\beta$ revealed by BACE enzyme cleavage, and an anti-rabbit-HRP conjugate for colorometric detection. Parenchymal C99 and sAPP $\beta$ levels were normalized to protein levels and expressed as nanograms per milligram of protein.

\section{Nonclinical bioanalytical methods for LY2886721}

Brain samples were weighed and a 3-fold volume of water/methanol $(4: 1, v / v)$ was added before homogenization with an ultrasonic tissue disrupter. Appropriate unlabeled internal standard was added to each brain, CSF, or plasma sample and supernatants were subjected to LC-MS/MS analysis using an Applied Biosystems/MDS Sciex API 4000 equipped with a TurboIonSpray interface and operated in positive ion mode monitoring the transition mass/charge $391 \rightarrow 96$.

\section{Plasma and brain protein binding}

LY2886721 plasma (mouse, dog, human) and brain (mouse) protein binding was determined in vitro using equilibrium dialysis, as described previously (Zamek-Gliszczynski et al., 2011). Unbound brain and plasma concentrations were derived by multiplying the total measured concentrations by the fraction unbound (free) determined in vitro.

\section{Statistical methods}

Statistical significance was determined by ANOVA using GraphPad Prism software (version 4). If significant, groups were compared by Dunnett's method of post hoc analysis to assess effects relative to vehicle control. Significance was set as $p \leq 0.05$.

\section{Methods for clinical studies}

Three randomized, placebo-controlled, subject- and investigator-blind, single-site, clinical studies were conducted to evaluate the safety, tolerability, pharmacokinetic (PK), and pharmacodynamic (PD) activity of LY2886721 after single- and multiple-dose administration. These studies were conducted in healthy male and female subjects. The clinical safety, tolerability, PK, and PD assessments after single doses of LY2886721 were derived from either Study 1 (1-35 mg of LY2886721; www.ClinicalTrials. gov identifier NCT01133405; BACA) or Study 3 (70 mg of LY2886721; www.ClinicalTrials.gov identifier NCT01534273; BACJ). Assessments after multiple doses of LY2886721 were derived from either Study 2 (5-35 mg of LY2886721; www.ClinicalTrials.gov identifier NCT01227252; BACB) or Study 3 (70 mg of LY2886721, BACJ). In multiple-dose assessments, LY2886721 was administered daily for $14 \mathrm{~d}$ over a dose range from 5-70 mg. All trials were conducted at PAREXEL Early Phase LA in compliance with the Declaration of Helsinki and the International Conference on Harmonisation/Good Clinical Practice guidelines. Ethical review board approval for Study 1 was given by the California Institutional Review Board. Ethical review board approval for Study 2 was given by the Cali- fornia Institutional Review Board; Aspire IRB, LLC; and the Health Sciences Institutional Review Board of the University of Southern California-Los Angeles. Ethical review board approval for Study 3 was given by Aspire IRB, LLC.

\section{Study design}

Single-dose evaluations. In single-dose assessments, plasma PK and PD effects on $\mathrm{A} \beta_{1-40}$ and $\mathrm{A} \beta_{1-42}$ concentrations were evaluated after single doses of placebo or 1, 7, 15, 25, 35 ( $n=6$ /group), or $70 \mathrm{mg}$ of LY2886721 $(n=10)$. Plasma samples were obtained immediately before dosing and up to $168 \mathrm{~h}$ after dosing, except for $70 \mathrm{mg}$, for which plasma samples were obtained up to $96 \mathrm{~h}$ after dosing. For the $1 \mathrm{mg}$ dose, plasma LY2886721 concentrations were generally below the limit of quantification and therefore these results are not reported.

The PK and PD of LY2886721 were subsequently assessed in CSF and plasma after administration of a single doses of 10 and $35 \mathrm{mg}$ of LY2886721 or placebo ( $n=4$ /group). CSF sampling was conducted as described previously (May et al., 2011). Briefly, serial CSF samples were collected through an indwelling subarachnoid lumbar catheter from $4 \mathrm{~h}$ before dosing up to $36 \mathrm{~h}$ after dosing.

Multiple-dose evaluations. In multiple-dose assessments, subjects $(n=$ $10 /$ group) received daily administration of study drug $(5,15,35$, or 70 $\mathrm{mg}$ ) or placebo for $14 \mathrm{~d}$. Plasma samples were obtained following the first dose for up to $24 \mathrm{~h}$ post dose, before the last dose (day 14) and for up to $120 \mathrm{~h}$ after dosing on day 14 . In addition, every $2 \mathrm{~d}$, plasma samples were collected before dosing to assess the time to reach steady state. CSF was sampled by a single lumbar puncture (LP) performed before dosing and again $\sim 24 \mathrm{~h}$ after administration of the last dose of LY2886721 or placebo on day 14. At each LP, a maximum of $25 \mathrm{ml}$ of CSF was collected for determination of $\mathrm{A} \beta_{1-40}, \mathrm{~A} \beta_{1-42}$, soluble amyloid precursor protein alpha $(\operatorname{sAPP} \alpha)$, soluble amyloid precursor protein beta $(\operatorname{sAPP} \beta)$, and LY2886721 concentrations. Any CSF sample that showed visual or laboratory evidence of blood contamination was excluded from the PK, PD, and statistical analyses.

For all studies, safety was assessed by recording adverse events (AEs), physical, neurological and ophthalmological examinations, vital signs, electrocardiograms (ECGs), and results of clinical safety laboratory tests.

\section{Bioanalytical methods}

Plasma $\mathrm{A} \beta_{1-40}$ and $\mathrm{A} \beta_{1-42}$ were measured simultaneously using a validated modification of the Fujirebio/Innogenetics INNO-BIA plasma amyloid- $\beta(\mathrm{A} \beta)$ forms assay run on a Luminex xMAP platform as described previously (Lachno et al., 2012). CSF $A \beta_{1-40}$ and $\mathrm{A} \beta_{1-42}$ were analyzed using validated modifications of the Fujirebio/Innogenetics INNOTEST $\beta$-AMYLOID $_{(1-42)}$ and prototype INNOTEST $\beta$-AMYLOID $(1-40)$ ELISA kits respectively as described previously (D.R. Lachno, B.A. Evert, K. Maloney, B.A. Willis, J.A. Talbot, M. Vandijck, R.A. Dean, unpublished data). CSF sAPP $\alpha$ and $\operatorname{sAPP} \beta$ were measured using a validated Meso Scale Discovery immunoassay as described previously (May et al., 2011).

\section{Clinical bioanalytical methods for LY2886721}

Human plasma and CSF samples were analyzed for LY2886721 using validated liquid chromatography with tandem-mass-spectrometric detection methods by Covance Laboratories. ${ }^{13} \mathrm{C}$-labeled LY2886721 was added to each sample as an internal standard. Separation was achieved using a gradient HPLC system with a Chromolith SpeedROD RP18-e column $(50 \times 4.6 \mathrm{~mm}$; Millipore $)$ using mobile phase A $(0.1 \%$ formic acid in water) and mobile phase B $[0.1 \%$ formic acid in acetonitrile: methanol (50:50, v:v)]. After separation, LY2886721 was detected using a Sciex API 5000 in positive ion mode monitoring the transition mass/ charge $391 \rightarrow 96$.

\section{$P K$ analysis}

PK parameter estimates for LY2886721 were calculated by standard noncompartmental methods of analysis using WinNonlin Enterprise (version 5.3). Clearance and apparent volume of distribution were reported for all subjects. Time of maximum concentration $\left(t_{\max }\right)$ and apparent terminal half-life $\left(t_{1 / 2}\right)$ were also reported. The accumulation ratio at steady state was calculated by dividing the area under the plasma concentration versus time period from time 0 to $24 \mathrm{~h}$ after administration 
$\left(\mathrm{AUC}_{(0-24)}\right)$ at steady state by $\mathrm{AUC}_{(0-24)}$ after the initial dose for each subject.

\section{$P D$ analysis}

For each subject with serially determined concentrations of plasma or CSF A $\beta_{1-40}$ and $\mathrm{A} \beta_{1-42}$, the time of the lowest observed concentration $\left(C_{\text {nadir }}\right)$ was reported, along with change from baseline at $C_{\text {nadir }}$ and the $24 \mathrm{~h}$ time-averaged change from baseline after dosing. Steady-state CSF $\mathrm{A} \beta_{1-40}, \mathrm{~A} \beta_{1-42}$, sAPP $\alpha$, and sAPP $\beta$ concentrations were expressed as a percentage change from baseline. Summary statistics were calculated for each PD parameter.

\section{Results}

Structural characterization of LY2886721

LY2886721 is composed of a bicyclic aminothiazine core along with fluorophenyl and fluoropyridine groups, themselves connected by an amide group. An x-ray co-crystal structure of LY2886721 bound in the BACE1 active site indicates that the bicyclic aminothiazine core engages the catalytic dyad of BACE1 while the fluorophenyl ring binds in the S1 pocket (Fig. 1, Table 1). This molecule also appears to engage in additional interactions with the BACE1 active site compared with LY2811376, including a potential hydrogen bond between the amide $\mathrm{N}-\mathrm{H}$ and a glycine residue present in the BACE1 active site and extension of the fluoropyridine group further into the S3 pocket.

\section{BACE1 and related aspartyl protease inhibition}

To determine the in vitro potency of inhibition, LY2886721 was tested against recombinant human BACE1 using a small synthetic FRET substrate (Table 2). LY2886721 demonstrated potent inhibition with an $\mathrm{IC}_{50}$ of $20.3 \mathrm{nM}$ (SD $10.1 \mathrm{nM}$ ). Assessment of LY2886721 activity against hBACE2 demonstrated an $\mathrm{IC}_{50}$ of $10.2 \mathrm{~nm}$ (SD $4.8 \mathrm{nM}$ ). BACE2 is a closely related aspartyl protease with a poorly understood function to date. Assessment of LY2886721 activity against cathepsin D, pepsin, renin, or other important aspartyl proteases showed essentially no inhibition $\left(\mathrm{IC}_{50}>100,000 \mathrm{nM}\right)$, suggesting that activity against these common aspartyl proteases is unlikely to be significant. Collectively, these data indicate that LY2886721 is a potent BACE1 aspartyl protease inhibitor with selectivity against cathepsin $D$, pepsin, and renin, but lacking selectivity against BACE2.

\section{Cellular assays}

Two different cellular models were used to assess the in vitro cellular activity of LY2886721 (Table 2). The HEK293Swe model consisted of a human embryonic kidney cell stably expressing a cDNA encoding human APP harboring a Swedish mutation. Overnight exposure of HEK293Swe cells to increasing concentrations of LY2886721 showed a concentration-dependent decrease in the amount of $\mathrm{A} \beta$ secreted into the condition medium. Consistent with a mechanism of BACE inhibition, the $\mathrm{EC}_{50}$ s for inhibition of $\mathrm{A} \beta_{1-40}$ and $\mathrm{A} \beta_{1-42}$ were essentially identical, 18.5 and $19.7 \mathrm{nM}$, respectively. These results were achieved in the absence of any overt cytotoxicity. Primary cortical neuronal cultures from embryonic PDAPP mice provided a second cellular model to assess BACE inhibition in vitro. In this assay, the APP sequence contained an Indiana mutation (APP $\left.{ }^{\mathrm{V} 717 \mathrm{~F}}\right)$, but the amino acid sequence around the BACE cleavage site was wild-type and, as such, was more reflective of the larger $\mathrm{AD}$ population. Overnight exposure of PDAPP neuronal cultures to an increasing concentration of LY2886721 produced a concentration-dependent decrease in $A \beta$ production. As observed in HEK293Swe cells, the $\mathrm{EC}_{50} \mathrm{~s}$ for inhibition of $\mathrm{A} \beta_{1-40}$ and $\mathrm{A} \beta_{1-42}$ were comparable in PDAPP neuronal cultures at $\sim 10 \mathrm{nM}$.

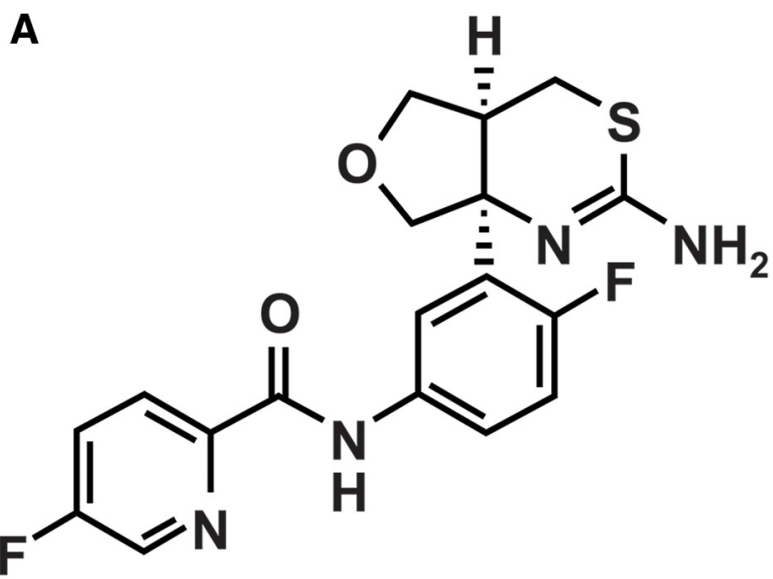

\section{LY2886721 \\ BACE1 IC ${ }_{50}=20.3 \mathrm{nM}$}

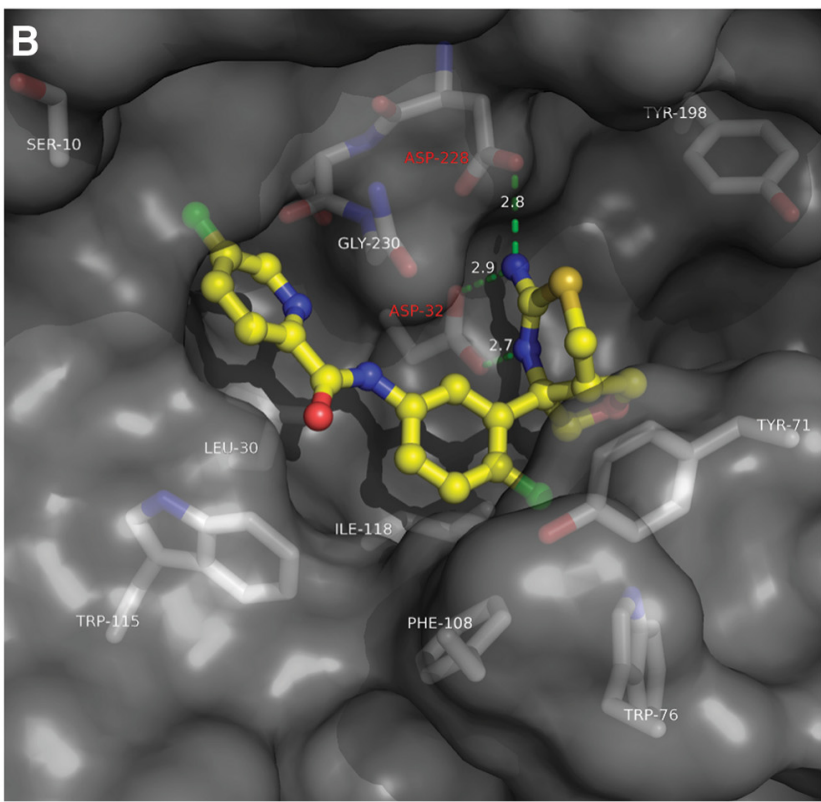

Figure 1. LY2886721: Compound structure $(\boldsymbol{A})$ and crystal structure of LY2886721 in the BACE1 active site $(\boldsymbol{B})$. Molecular surface is shown in gray, with Thr72 and Gln73 omitted for clarity. Carbon atoms are colored white or yellow. Oxygen, nitrogen, sulfur, and fluorine atoms are colored red, blue, yellow, and green, respectively. Dashed lines represent hydrogen bond contact distances between LY2886721 and the catalytic Asp residues (in A). Structure factors and protein coordinates will be deposited into the Protein Data Bank. The figure was generated using PyMOL (Schroedinger, LLC).

Nonclinical characterization of LY2886721 in mice and dogs PDAPP mouse studies

The in vivo pharmacology properties of LY2886721 were initially tested in the PDAPP mouse, a transgenic mouse expressing a mini-gene for human APP harboring an APP ${ }^{\mathrm{V} 717 \mathrm{~F}}$ mutation (Games et al., 1995). In an oral acute dose-response study, young PDAPP mice ( $n=6-8$ per group) received vehicle (7\% Pharmasolve) or 3,10 , or $30 \mathrm{mg} / \mathrm{kg}$ doses of LY2886721 and were killed 3 h later. Hippocampal (Fig. 2A) and cortical (Fig. 2B) levels of $\mathrm{A} \beta_{1-\mathrm{x}}$ were significantly reduced by all 3 doses of LY2886721 compared with the vehicle. These robust effects were associated with the following unbound brain exposures at $3 \mathrm{~h}$ after dose: 2.3, 11, and $50 \mathrm{~nm}$ at 3,10 , and $30 \mathrm{mg} / \mathrm{kg}$, respectively. 


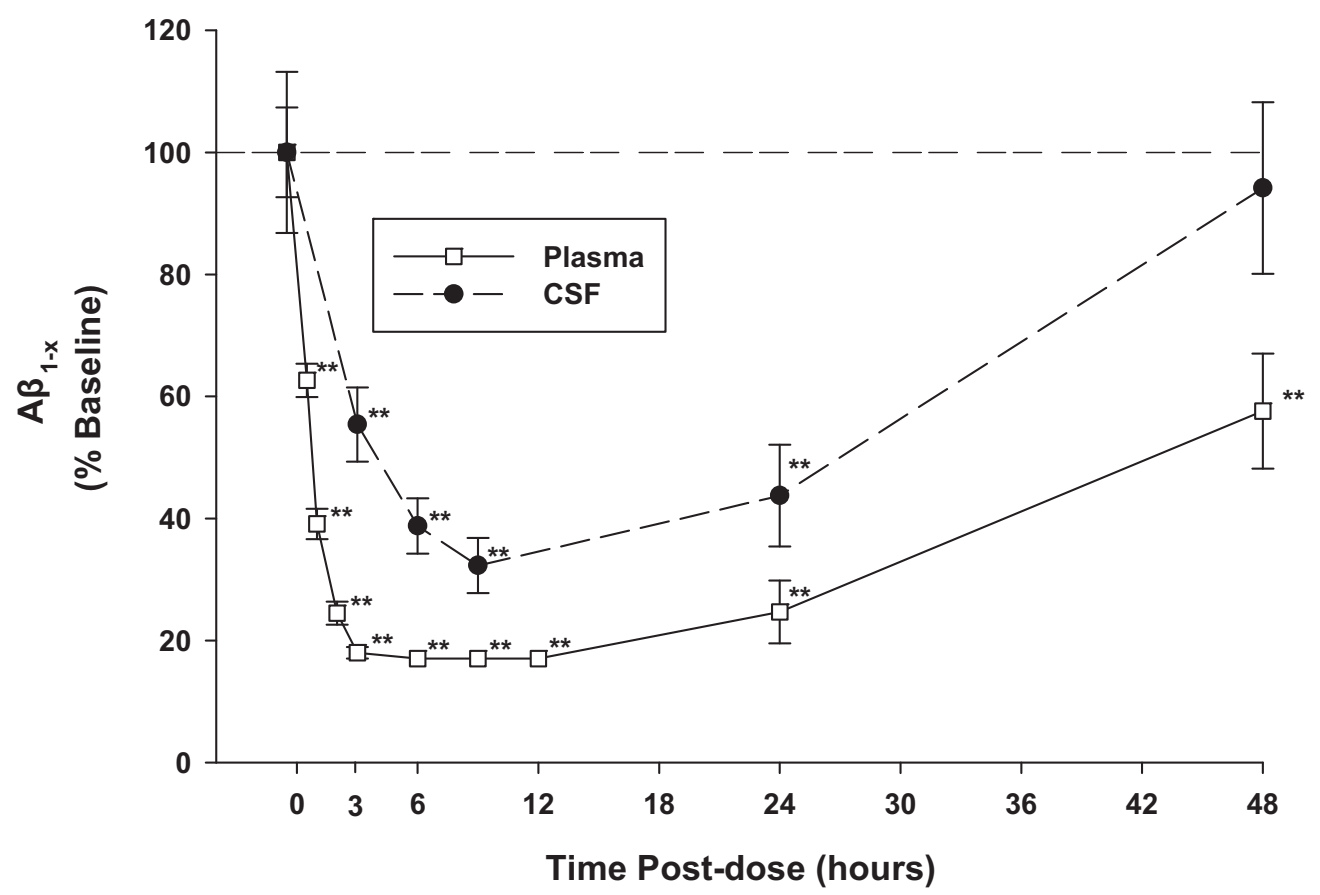

Figure 3. Peripheral and central PD effects of LY2886721 in beagle dogs after a single $1.5 \mathrm{mg} / \mathrm{kg}$ dose. Baseline plasma and CSF samples were collected from cannulated beagle dogs $(n=6)$ before dosing with $1.5 \mathrm{mg} / \mathrm{kg}$ LY2886721. After dosing, plasma and CSF samples were collected at various times and stored for analysis; $A \beta_{1-x}$ levels are measured in plasma and CSF and averaged across all 6 animals. Baseline plasma $A \beta_{1-x}$ was $234 \pm 17 \mathrm{pg} / \mathrm{ml}$ (mean \pm SEM; $n=6$ ) and baseline CSF $A \beta_{1-x}$ was $4.85 \pm 0.64 \mathrm{ng} / \mathrm{ml}$ (mean \pm SEM; $n=6$ ). LY2886721 produced robust and time-dependent decreases in $A \beta_{1-x}$ in both plasma and CSF of dog relative to baseline. ${ }^{* *} p<0.01$ compared with baseline. $p$-values derived from ANOVA: Dunnett's post hoc analysis.

ble changes in all $\mathrm{A} \beta$ isoforms are consistent with the inhibition of the BACE1 protease. These prominent PD effects were associated with peripheral exposures averaging an unbound drug AUC of $1383 \pm 754 \mathrm{~nm} / \mathrm{h}($ mean $\pm \mathrm{SD} ; n=6)$ and a free drug maximum concentration $\left(C_{\max }\right)$ at $1 \mathrm{~h}$ after dose of $118 \pm 32 \mathrm{nM}$ (mean $\pm \mathrm{SD} ; n=6)$. The total drug exposure in CSF averaged $1222 \pm 730 \mathrm{~nm} / \mathrm{h}($ mean $\pm \mathrm{SD} ; n=6)$, which is comparable to the free unbound exposure of drug in plasma, suggesting excellent brain permeability for LY2886721.

Clinical characterization of LY2886721 in healthy volunteers A total of 95 subjects were enrolled in all 3 studies. Subject characteristics for each study are shown in Table 3.

\section{$P K$}

Single-dose plasma concentrations of LY2886721 were generally not quantifiable after the $1 \mathrm{mg}$ of dose, so no PK parameters were estimated at this dose level. After single doses of 5-70 mg of LY2886721, the plasma concentrations rose, reaching a maximum concentration at a median of $3 \mathrm{~h}$ after dose (range $1-8 \mathrm{~h}$ ), and then fell in a multiexponential manner. The geometric mean terminal elimination $t_{1 / 2}$ was determined to be $17.2 \mathrm{~h}$ (range $8.19-36.3 \mathrm{~h}$ ). The $\mathrm{PK}$ appeared to be linear with respect to dose; the geometric mean apparent oral clearance was $34.8 \mathrm{~L} / \mathrm{h}(38 \% \mathrm{CV})$ and the apparent volume of distribution during the terminal phase was $863 \mathrm{~L}$ (56\% CV) across dose levels. The PK of LY2886721 was consistent between studies.

Serial CSF sampling was conducted at doses of 10 and $35 \mathrm{mg}$. Maximum concentration of LY2886721 in CSF were reached at $\sim 5 \mathrm{~h}$ after dosing (range 3-6 h). The mean $\mathrm{AUC}_{(0-\infty)}$ in CSF was $18.4 \%$ ( $10 \mathrm{mg}$ dose) to $15.1 \%$ (35 mg dose) of the total $\mathrm{AUC}_{(0-\infty)}$ observed in plasma (data not shown). At $24 \mathrm{~h}$ after a $70 \mathrm{mg}$ dose, the geometric mean $(\% \mathrm{CV})$ CSF concentration was $6.71 \mathrm{ng} / \mathrm{ml}$
Table 3. Subject characteristics by study

\begin{tabular}{lccc}
\hline & $\begin{array}{l}\text { Study 1: } \\
\text { SAD }(n=39)\end{array}$ & $\begin{array}{l}\text { Study 2: } \\
\operatorname{MAD}(n=42)\end{array}$ & $\begin{array}{l}\text { Study 3: } \\
\text { SAD and MAD }(n=15)^{*}\end{array}$ \\
\hline $\begin{array}{l}\text { Age, } y \\
\quad \text { Mean (SD) }\end{array}$ & $37.0(18.8)$ & $31.0(7.5)$ & $32.9(10.0)$ \\
$\begin{array}{l}\text { Weight, } \mathrm{kg} \\
\quad \text { Mean (SD) }\end{array}$ & $74.6(13.7)$ & $76.7(14.0)$ & $78.1(9.5)$ \\
$\begin{array}{l}\text { Female sex, } \mathrm{n}(\%) \\
\text { Race, } \mathrm{n}(\%)\end{array}$ & $6(15.4)$ & $3(7.1)$ & $0(0.0)$ \\
$\quad$ & & & \\
White & $11(28.2)$ & $20(47.6)$ & $8(53.3)$ \\
Asian & $12(30.8)$ & $14(33.3)$ & $4(26.7)$ \\
$\quad$ Black & $13(33.3)$ & $8(19.0)$ & $2(13.3)$ \\
\hline
\end{tabular}

${ }^{*} n$ represents those subjects of a total of 30 enrolled in Study 3 who received doses of $70 \mathrm{mg}$ of LY2886721 or placebo; 10 subjects received at least a single dose of LY2886721 and 5 subjects had placebo.

(31\%). On average, these concentrations were $18.6 \%$ of the total concentration measured in plasma when measured at the same time (range $12.8-22.8 \%$ ).

In the multiple-dose evaluations, steady state was achieved $\sim 4-8 \mathrm{~d}$ after the start of daily dosing. At steady state across doses, the median $t_{\max }$ was $4 \mathrm{~h}$ after dose (range $1-8 \mathrm{~h}$ ). The mean terminal $t_{1 / 2}$ estimates value was $23.2 \mathrm{~h}(36.1 \% \mathrm{CV})$. Clearance at steady state was similar to that observed after single doses, with an overall mean value of $35.4 \mathrm{~L} / \mathrm{h}$ (32.7\% CV). After repeated daily doses, some accumulation of LY2886721 was observed. Across dose groups, the mean accumulation ratio (RA) was $1.43(26.5 \% \mathrm{CV})$.

\section{$P D$}

Single-dose plasma A $\beta$ PD. After single doses of LY2886721, plasma $\mathrm{A} \beta_{1-40}$ and $\mathrm{A} \beta_{1-42}$ concentrations decreased significantly, reached a nadir, and then slowly returned to predose baseline values (Fig. 4). The time at which the nadir occurred ranged from a mean of 6 to $12 \mathrm{~h}$ and appeared to be independent of dose. The 


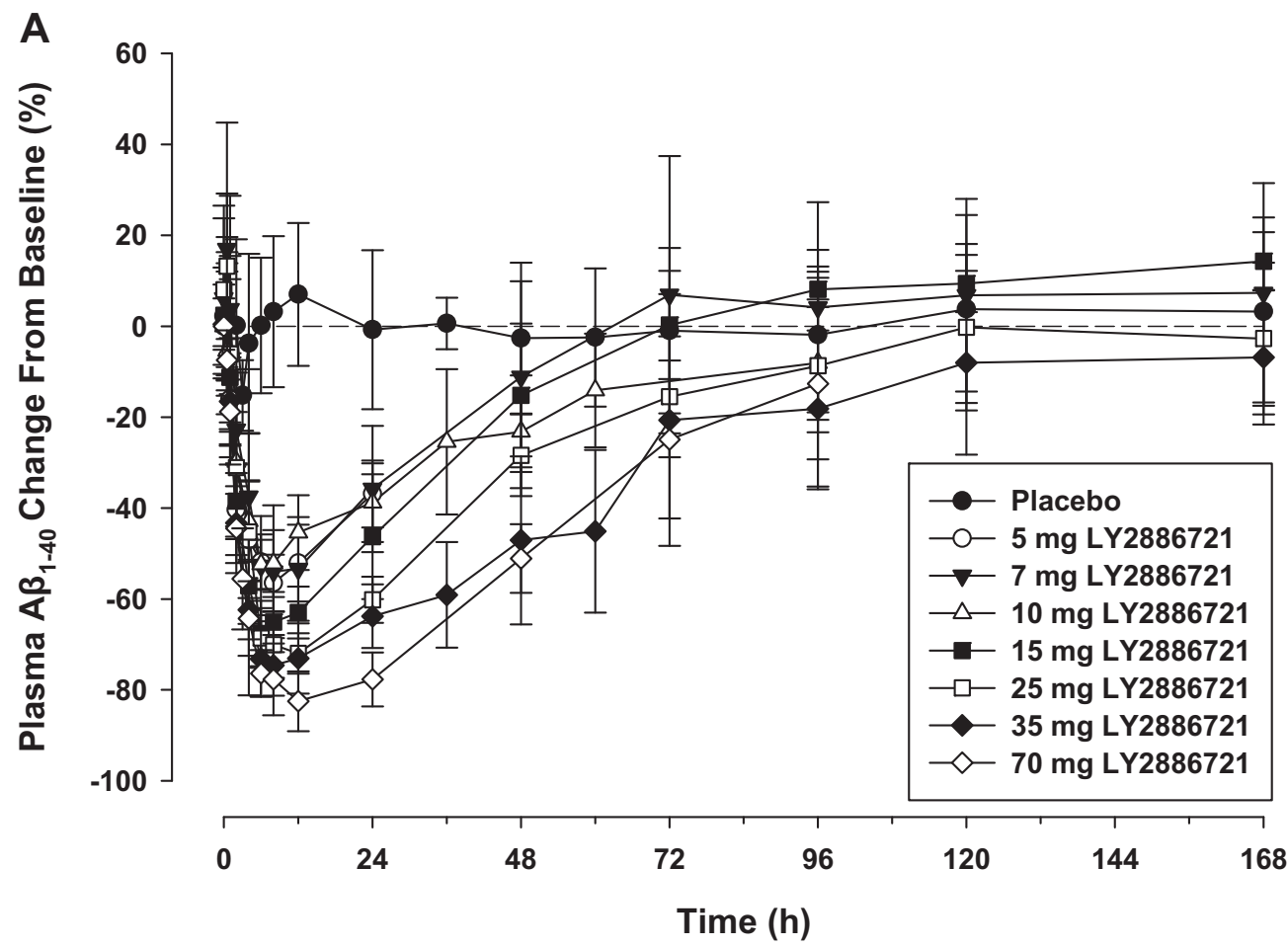

B

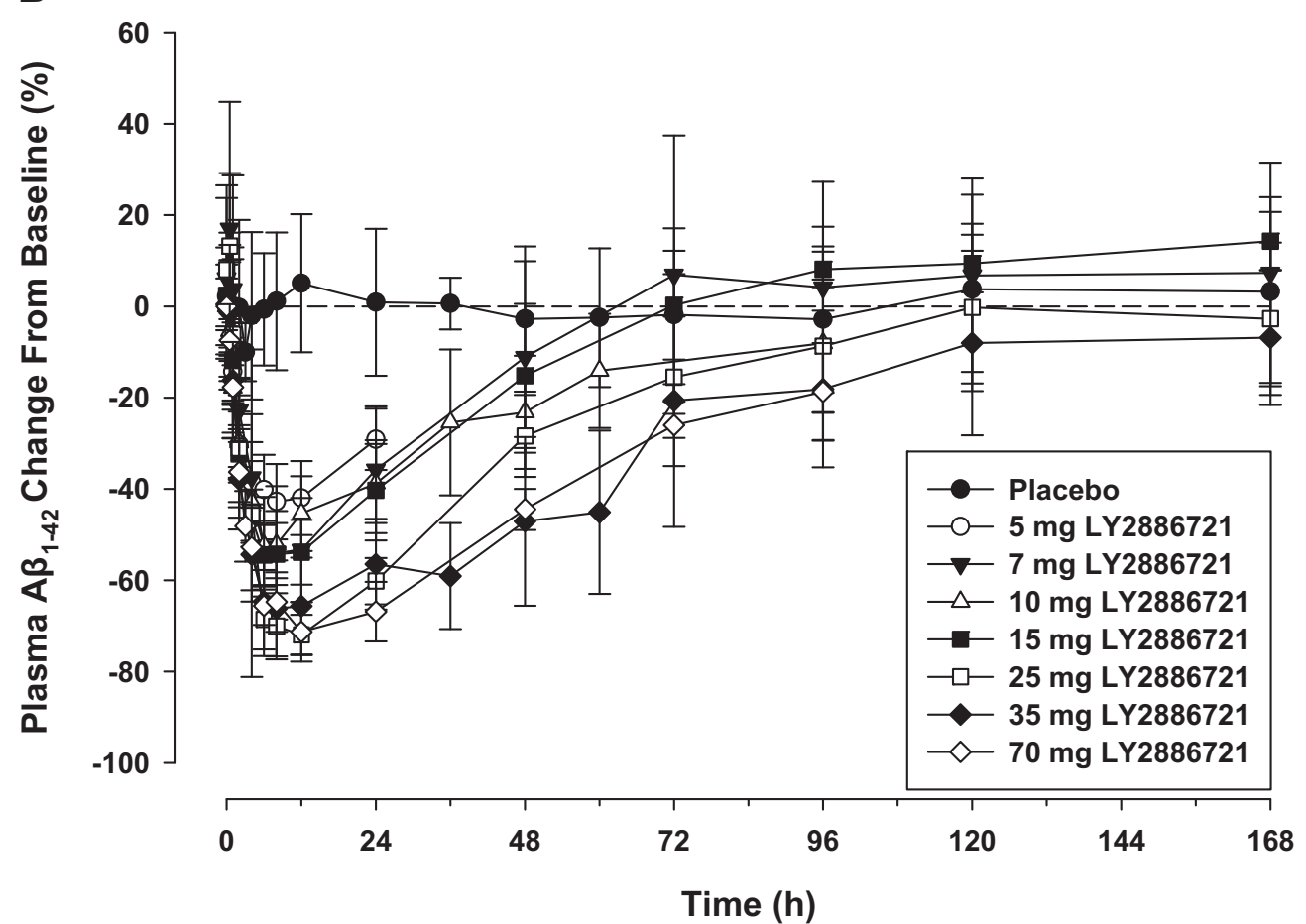

Figure 4. Plasma $A \beta$ species by time course in humans after administration of a single dose of $5,7,10,15,25,35$, and $70 \mathrm{mg}$ of $L Y 2886721$ in healthy subjects. Subjects received a single dose of $5,7,10,15,25,35$, or $70 \mathrm{mg}$ of LY2886721 ( $n=$ at least $6 /$ dose) or placebo. Samples were drawn for PD biomarkers at baseline and at times up to $168 \mathrm{~h}$ after dosing. The time at which the mean nadir occurred across $L Y 2886721$ doses was $6-12 \mathrm{~h}$ and appeared to be independent of dose. The reduction from baseline in levels of $A \beta$ species, as measured by either the nadir or the average reduction over the first $24 \mathrm{~h}$, tended to increase with increasing doses of $L Y 2886721$. At the highest dose, $70 \mathrm{mg}$, the reduction from baseline was $83.3 \%$ for plasma concentrations of $A \beta_{1-40}(A)$ and $74.0 \%$ for $A \beta_{1-42}(B)$. Plasma levels of $A \beta_{1-40}$ and $A \beta_{1-42}$ slowly approached baseline levels by $168 \mathrm{~h}$.

magnitude of the decrease in plasma $\mathrm{A} \beta_{1-40}$ and $\mathrm{A} \beta_{1-42}$, as measured either by the nadir or the average reduction over the first $24 \mathrm{~h}$, tended to increase with increasing doses of LY2886721. For the $70 \mathrm{mg}$ dose, the change from baseline at nadir in $\mathrm{A} \beta_{1-40}$ and $\mathrm{A} \beta_{1-42}$ was $-83.3 \pm 4.74 \%$ and $-74.0 \pm 6.80 \%$, respectively.
Single-dose CSF A $\beta$ PD. A single $35 \mathrm{mg}$ dose of LY2886721 decreased $\mathrm{A} \beta_{1-40}$ and $\mathrm{A} \beta_{1-42}$ concentrations in serially collected CSF specimens. This effect was first apparent $\sim 4 \mathrm{~h}$ after dosing. The time to reach nadir concentrations varied widely between subjects, with median times of $\sim 17 \mathrm{~h}$ after dose administration. 


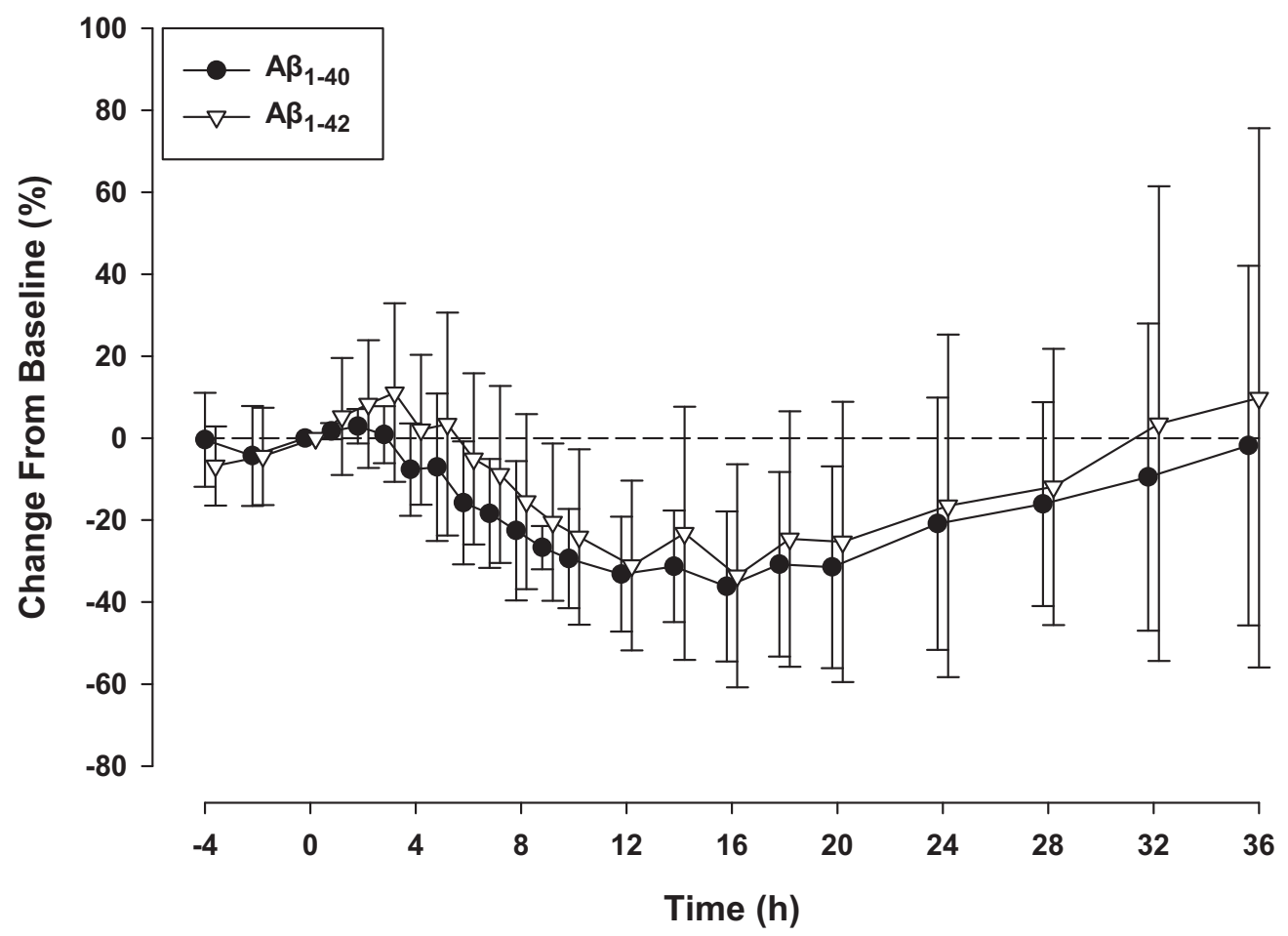

Figure 5. CSF levels of amyloid $\beta$ species after a single dose of $35 \mathrm{mg}$ of $L Y 2886721$ in healthy subjects $(n=4)$. CSF concentrations of $A \beta_{1-40}$ and $A \beta_{1-42}$ closely paralleled one another after a single $35 \mathrm{mg}$ dose of $\mathrm{L} Y 2886721$. The mean nadir for both species occurred at $18 \mathrm{~h}, \sim 6-12 \mathrm{~h}$ after the plasma nadir occurred. At nadir, the mean reduction from baseline was $40.0 \%$ for $A \beta_{1-40}$ and $36.3 \%$ for $A \beta_{1-42}$, approximately half the reduction seen in plasma at the same dose. After concentrations reached nadir, they slowly returned to their predose baseline values over $32-36 \mathrm{~h}$.

Although the CSF $\mathrm{A} \beta_{1-40}$ and $\mathrm{A} \beta_{1-42}$ change from baseline after the single $35 \mathrm{mg}$ doses of LY2886721 was qualitatively similar for both isoforms, the percentage change for $A \beta_{1-40}$ was slightly greater than for $\mathrm{A} \beta_{1-42}$, as shown in Figure 5 .

Multiple-dose plasma $A \beta$ PD. After $14 \mathrm{~d}$ of daily dosing, administration of 5-70 mg of LY2886721 dose-dependently decreased concentrations of $\mathrm{A} \beta_{1-40}$ and $\mathrm{A} \beta_{1-42}$ in plasma serially collected after the last dose. The observed percentage decreases in plasma $\mathrm{A} \beta_{1-40}$ relative to baseline were quantitatively greater than that observed for plasma $\mathrm{A} \beta_{1-42}$. The median time at which a nadir was reached for the $2 \mathrm{~A} \beta$ isoforms after the final daily dose of 35 and $70 \mathrm{mg}$ of LY2886721 was 6-10 h (Fig. 6).

Multiple-dose CSF A $\beta$ PD. After $14 \mathrm{~d}$ of daily dosing, administration of placebo or increasing doses of LY2886721 revealed dose-dependent decreased concentrations of $A \beta_{1-40}$ and $A \beta_{1-42}$ in CSF collected $\sim 24 \mathrm{~h}$ after the last dose. The mean $( \pm \mathrm{SD}$ ) $\mathrm{A} \beta_{1-40}$ percentage change from baseline for placebo, 5, 15, 35, and $70 \mathrm{mg}$ was $-0.58 \%$ ( \pm 8.67$),-17.7 \%$ ( \pm 4.99$),-29.1 \%$ $( \pm 7.15),-57.6 \%$ ( \pm 5.00$)$, and $-74.4 \%( \pm 1.68)$, respectively (Fig. 7). The mean ( \pm SD) $\mathrm{A} \beta_{1-42}$ percentage change from baseline for placebo, $5,15,35$, and $70 \mathrm{mg}$ was $-4.96 \%( \pm 8.34)$, $-20.1 \%$ ( \pm 1.26$),-30.0 \%$ ( \pm 10.4$),-53.2 \%$ ( \pm 3.95$)$, and $-71.3 \%$ $( \pm 1.59)$, respectively (Fig. 7).

Multiple-dose CSF $s A P P \alpha$ and $s A P P \beta P D$. To examine LY2886721 target engagement and the indirect and direct impact of BACE inhibition on APP processing, concentrations of CSF sAPP $\alpha$ and sAPP $\beta$ were measured after repeated daily dosing for $14 \mathrm{~d}$. CSF was collected before and $\sim 24 \mathrm{~h}$ after the final day 14 administration of placebo or one of the LY2886721 treatments. There was a clear dose-response relationship from placebo to $70 \mathrm{mg}$ daily dosing for the mean change from baseline in CSF measurements of sAPP $\alpha$ and sAPP $\beta$. The mean ( \pm SD) CSF sAPP $\beta$ decreases from baseline at $24 \mathrm{~h}$ for placebo, 5, 15, 35, and $70 \mathrm{mg}$ were
7.75\% ( \pm 15.8 ), $22.1 \%$ ( \pm 17.0 ), 35.8\% ( \pm 6.50 ), 59.0\% ( \pm 5.47 ), and $77.4 \%( \pm 3.11)$, respectively. The mean (SD) CSF sAPP $\alpha$ increases from baseline at $24 \mathrm{~h}$ for placebo, 5, 15, 35, and $70 \mathrm{mg}$ were $-5.56 \%$ ( \pm 10.3 ), $7.74 \%$ ( \pm 14.1$), 48.2 \%$ ( \pm 12.3 ), $74.4 \%$ ( \pm 9.02 ), and $59.1 \%( \pm 22.7)$ (Fig. 7).

\section{Safety}

Overall, there were no serious AEs reported for LY2886721 administered up to $70 \mathrm{mg}$ as single or multiple doses. In addition, no subject withdrew from the study because of an AE. Two subjects experienced transient elevations in liver function enzymes. Both were asymptomatic and occurred without bilirubin elevation. One subject experienced elevated serum aspartate aminotransferase (AST, peak $3 \times \mathrm{ULN}$ ) and alanine aminotransferase [ALT, peak $4 \times$ upper limit of normal (ULN)], after a single dose of $35 \mathrm{mg}$ of LY2886721, which returned to baseline 2 weeks after dosing. The other subject experienced transient mild elevations in AST (peak 1.9 × ULN $5 \mathrm{~d}$ after dose) and ALT (peak $3.3 \times$ ULN peak $5 \mathrm{~d}$ after dose) following a single dose of $70 \mathrm{mg}$ of LY2886721, which returned to ULN within 2 months after discontinuation of the study drug. The most common AEs after single-dose administration of LY2886721 were dizziness and headache. The most common AEs after multiple-dose administration of LY2886721 were procedural headache $(n=2)$ and 1 occurrence each of headache, visual field test abnormality, orthostatic hypotension, libido decrease, sinus congestion, chest pain, oral herpes, viral infection, muscle spasm, cough, insomnia, and rash (Table 4). AEs were generally mild to moderate in severity. The most common AEs associated with CSF collection were a postprocedural headache and puncture site pain. There were no clinically significant findings in vital signs, ECGs (including QTc interval), neurological, or ophthalmological examinations. Clin- 


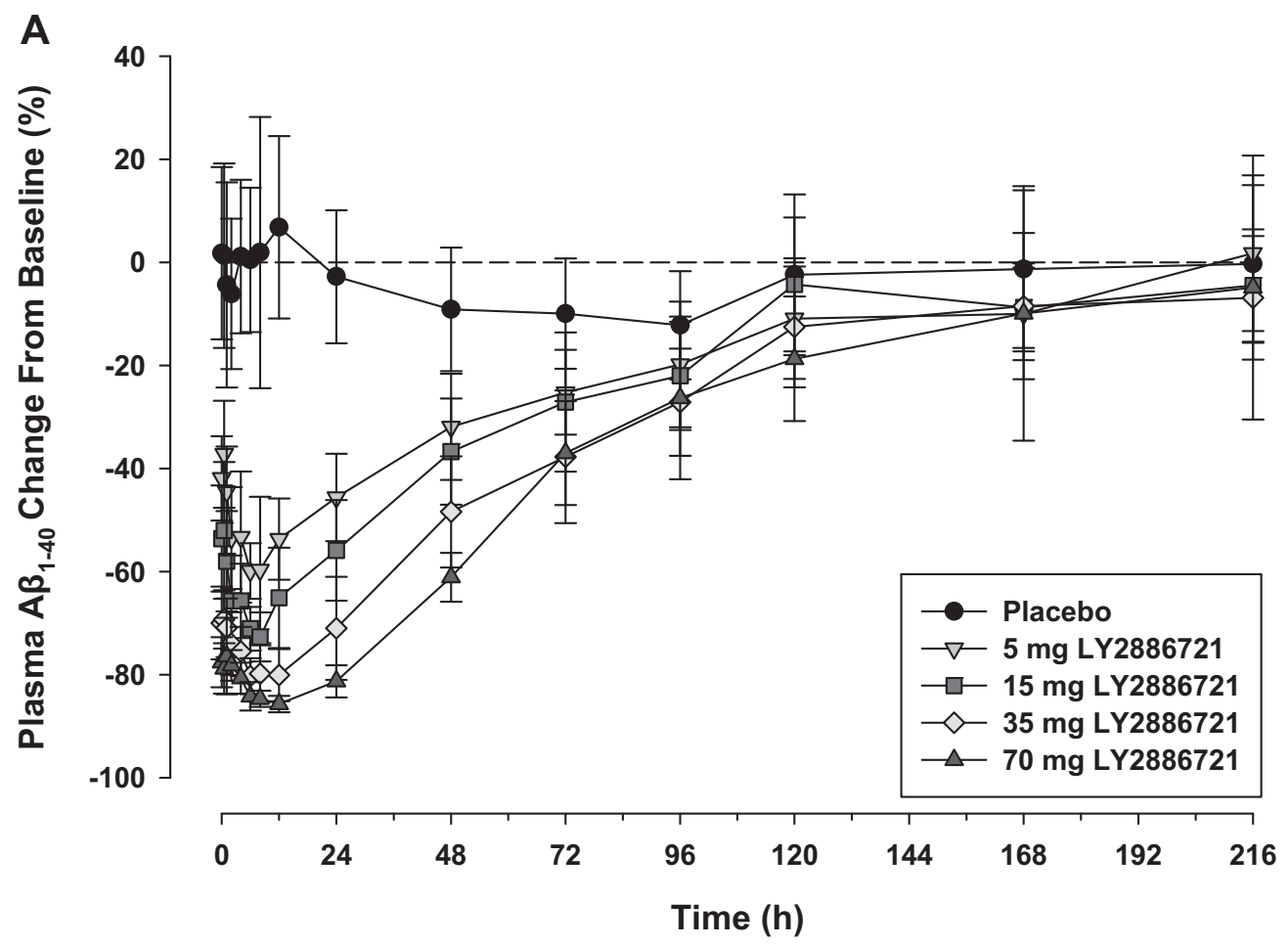

B

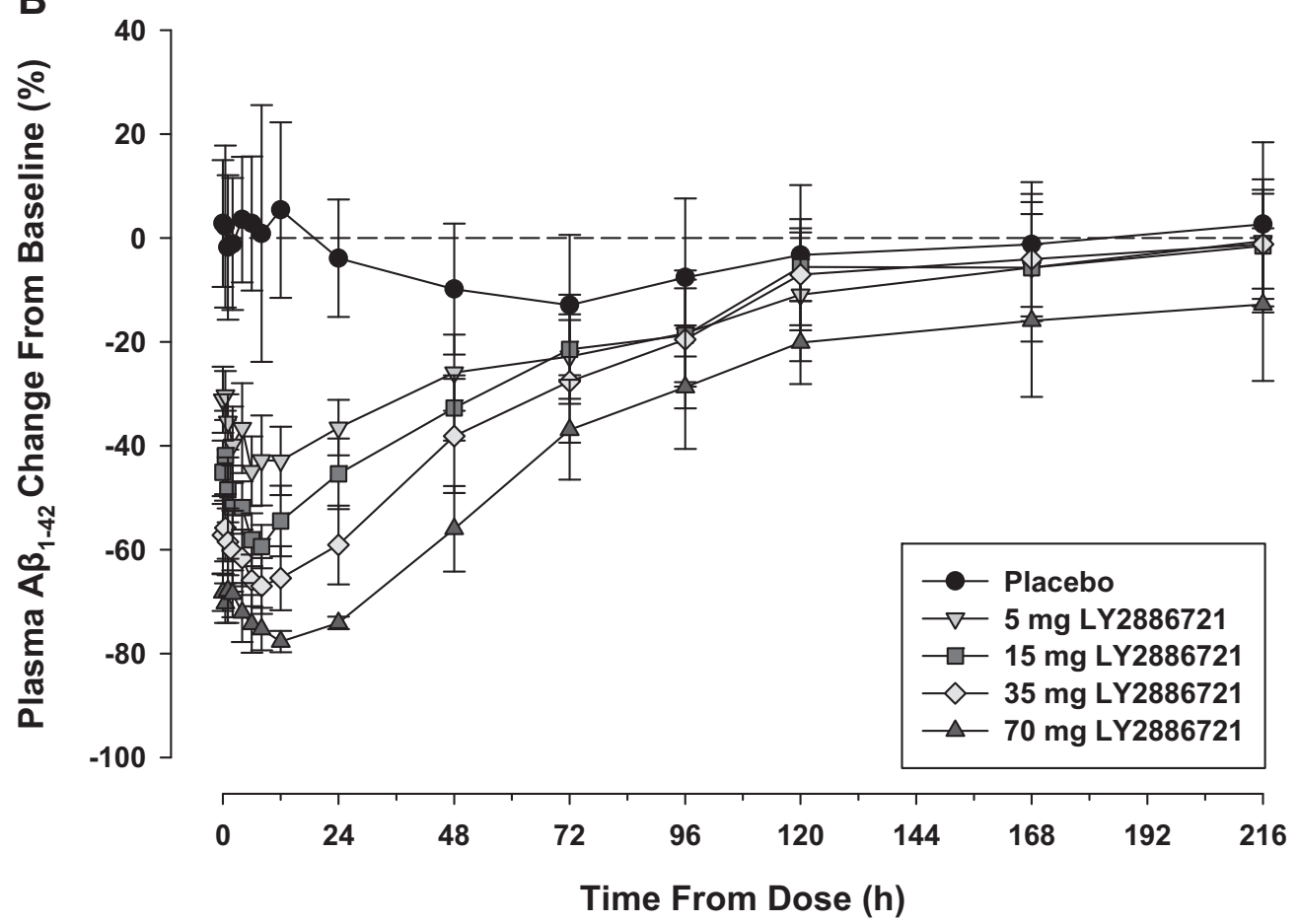

Figure 6. Steady-state plasma $A \beta$ species time course in humans after once daily administration of $5,15,35$, or $70 \mathrm{mg}$ of $L Y 2886721$ for 14 din healthy human subjects. Healthy subjects ( $n=$ 6-10 per dose group) received daily doses of 5, 15,35, or $70 \mathrm{mg}$ of $L Y 2886721$ for $14 \mathrm{~d}$. After the last dose, plasma samples were collected for up to $216 \mathrm{~h}$ and analyzed for $A \beta_{1-40}$ and $A \beta_{1-42}$. Values are expressed as the percentage change from baseline levels. Both $A \beta$ species were reduced compared with placebo, reached a nadir, and slowly approached baseline by the end of the sampling period (216 h). $A, A \beta_{1-40}$ concentrations were reduced and reached a nadir at $8 \mathrm{~h}$ for the 3 lower doses and $9 \mathrm{~h}$ for the highest dose of $70 \mathrm{mg}$. Whether measured as change from baseline or time-averaged change from day 1 baseline from $0-24 \mathrm{~h}$, the percentage reduction from baseline increased with dose (reduction from baseline at nadir: $66.3 \%, 73.5 \%, 83.5 \%$, and $86.4 \%$ for 5,15 , 35 , and $70 \mathrm{mg}$, respectively). $B$, Concentrations of $A \beta_{1-42}$ were reduced in a similar manner. Steady-state $A \beta_{1-42}$ concentrations reached a mean nadir at between 8 and $10 \mathrm{~h}$ and reductions from baseline concentrations after $14 \mathrm{~d}$ of a steady dose ranged from $47.1 \%$ to $80.1 \%$. 


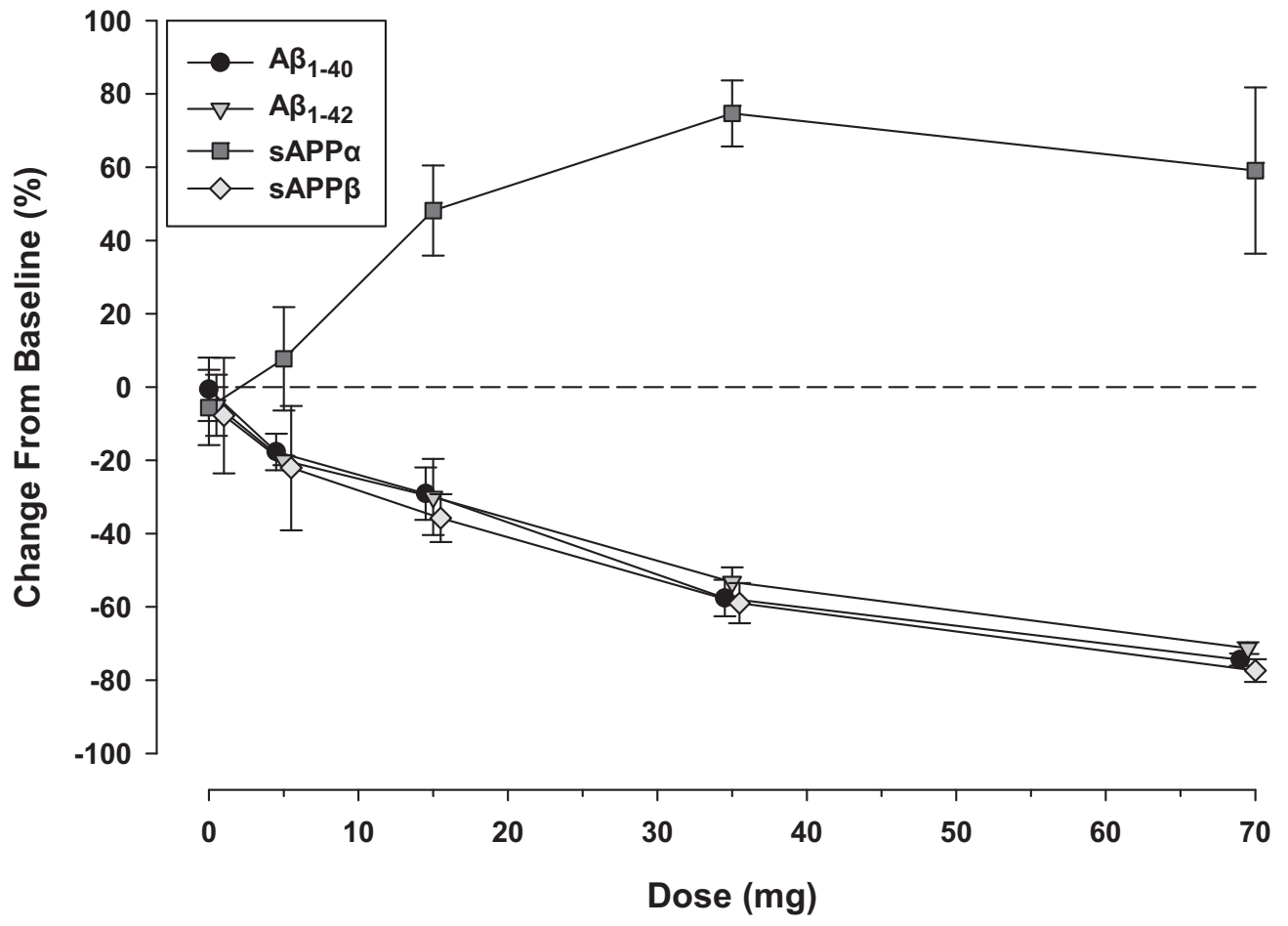

Figure 7. Comparison of CSF $A \beta_{1-40}, A \beta_{1-42}, S A P P \alpha$, and SAPP $\beta$ at steady state by dose after daily administration of LY2886721 in healthy subjects. Subjects received daily doses of $L Y 2886721$ for $14 \mathrm{~d}$. On day $15,24 \pm 4$ h after the last dose of LY2886721 on day 14 , CSF samples were collected for measurement of $A \beta_{1-40}, A \beta_{1-42}, S A P P \alpha$, and sAPP $\beta$. Values are expressed as the percentage change from baseline levels. As the dose increased, increasing reductions in CSFA $\beta_{1-40}, A \beta_{1-42}$, and sAPP $\beta$ were observed. At the 35 mg dose, the mean level of decrease in CSFA $\beta_{1-40}$, $A \beta_{1-42}$ and sAPP $\beta$ was between $53.2 \%$ and $59.0 \%$ of baseline levels. At the $70 \mathrm{mg}$ dose, the decrease was between $71 \%$ and $78 \%$ (all $p<0.001$, as determined by ANCOVA analysis). In contrast, sAPP $\alpha$ demonstrated a clear dose-dependent increase with a maximum increase of $60 \%$ and $80 \%$ of baseline for the 35 and $70 \mathrm{mg}$ dose levels, respectively.

Table 4. Adverse event profile after administration of multiple doses of LY2886721

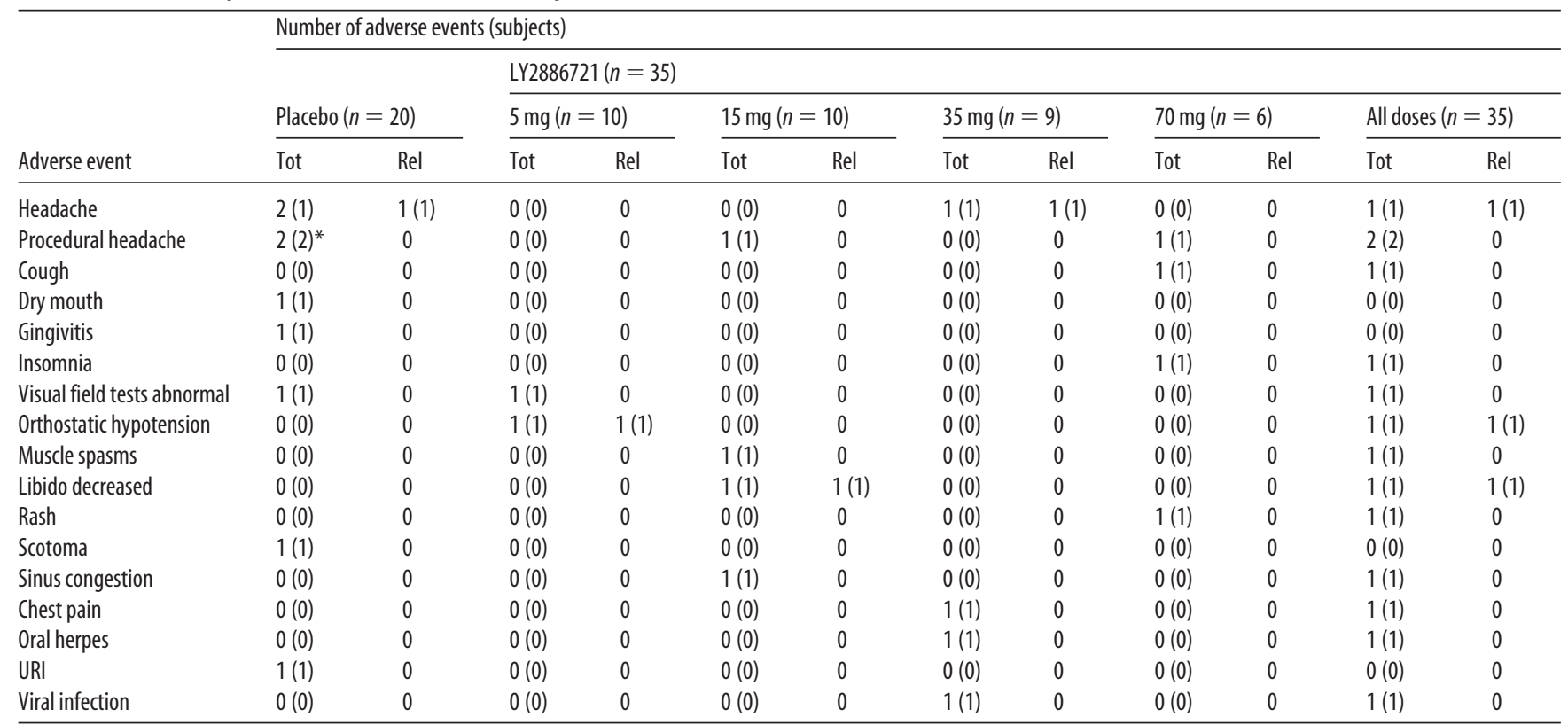

Adverse event, all-cause and related to study drug, by treatment, in order of frequency.

Rel, Related to study drug; Tot, total; URI, upper respiratory tract infection.

*Only this adverse event was moderate in severity and all others were mild in severity. None was considered severe.

ical laboratory tests were unremarkable aside from transiently elevated liver enzyme activities described previously.

\section{Discussion}

BACE1 is positioned at the very top of the amyloid cascade hypothesis by virtue of its initiating role in the production of $A \beta$ peptide. Following a significant lag time after the cloning of BACE1 in 1999 (Vassar et al., 1999; Sinha et al., 1999), several smallmolecule inhibitors of this enzyme entered clinical development. LY2811376 was the first small-molecule BACE1 inhibitor reported to produce robust PD responses of plasma and CSF $A \beta$ in human subjects (May et al., 2011). However, clinical development of that 
molecule was halted after the discovery of retinal epithelial pathology in nonclinical toxicology studies (May et al., 2011).

Herein, we report the nonclinical and phase 1 clinical data for LY2886721, a potent small-molecule, active-site inhibitor of BACE1. Compared with LY2811376, LY2886721 demonstrates 10 -fold more potent inhibition of BACE1 and significantly reduced potency against cathepsin D, a key off-target protease. Reduced potency also was observed against pepsin and renin, thereby resulting in substantially increased protease selectivity compared with LY2811376 (May et al., 2011). The intrinsic potency of LY2886721 against purified recombinant enzyme is maintained in two cell-based assays indicating good access to BACE1 expressed in its normal cellular compartments. Moreover, LY2886721 produced robust dose-dependent reductions in hippocampal and cortical $\mathrm{A} \beta, \mathrm{C} 99$, and $\operatorname{APP} \beta$ levels after oral dosing in a PDAPP transgenic mouse model. This constellation of changes in APP-processing catabolites is consistent with a mechanism of BACE1 inhibition in vivo. Finally, in a cannulated beagle dog model that permits continuous sampling of CSF, oral administration of $1.5 \mathrm{mg} / \mathrm{kg}$ LY2886721 produced significant and persistent $A \beta$ lowering in CSF. CSF concentrations of LY2886721 in this study approximated free plasma concentrations, suggesting that the increase in BACE1 potency displayed by LY2886721 relative to LY2811376 was achieved without compromising CNS penetration. This robust pharmacology, coupled with a nonclinical toxicology profile without adverse retinal epithelial pathology at pharmacologic doses (as seen previously with LY2811376), led to the advancement of LY2886721 into early phase clinical trials.

Accordingly, a series of single ascending dose (SAD) and multiple ascending dose (MAD) studies were conducted in healthy subjects with LY2886721. In SAD studies, a robust PK/PD relationship was observed after single doses of LY2886721, as evidenced by dose-dependent, statistically significant reductions in plasma $\mathrm{A} \beta_{1-40}$ and $\mathrm{A} \beta_{1-42}$ that correlated well with free drug concentrations in plasma. Similarly, a single $35 \mathrm{mg}$ dose of LY2886721 produced a robust (40\% relative to baseline) and sustained (nadir at $18 \mathrm{~h}$ after dosing) reduction in $\mathrm{CSF} A \beta_{1-40}$ and $\mathrm{A} \beta_{1-42}$. As in the cannulated dog study, CSF concentrations of LY2886721 approximated free drug concentrations in plasma, providing further evidence that LY2886721 is freely permeable across the blood-brain barrier. In MAD studies in which repeated doses of LY2886721 were administered over $14 \mathrm{~d}$, plasma PD responses observed on the last day of dosing were moderately greater than those in the SAD studies at comparable doses, consistent with the higher plasma concentrations of LY2886721 at steady state compared with that after a single dose. For a similar reason, there was a larger PD response in lumbar CSF sampled $24 \mathrm{~h}$ after the last of $14 \mathrm{~d}$ of dosing compared with PD evaluations in CSF during single-dose studies. Consistent with BACE1 inhibition in vivo, there were comparable dose-dependent reductions in CSF SAPP $\beta$, the proximal cleavage product of BACE1 on APP, and largely concomitant opposite effects on CSF sAPP $\alpha$, suggestive of enhanced nonamyloidogenic processing of APP with BACE1 inhibition.

These robust PD effects were obtained in the absence of significant AEs. No clinically significant findings were reported for LY2886721 across the three clinical studies apart from transiently elevated liver enzymes in two subjects. Collectively, these data suggest that LY2886721 can be administered to humans at doses demonstrating significant target engagement for up to 2 weeks without significant AEs.
Based in part on the results described herein, a phase 2 study was conducted to examine the safety, tolerability, and PD effects of LY2886721 in patients with mild cognitive impairment due to AD or mild AD (www.ClinicalTrials.gov identifier NCT01561430). During the course of the study, routine safety monitoring detected abnormal liver enzyme elevations in 4 patients of 70 (unpublished data) and, therefore, Lilly chose to terminate the study. Although 2 subjects exhibited elevated ALT and AST in the phase 1 studies reported herein, there was no dose dependency in severity or incidence observed, so the relationship to LY2886721 for the abnormal liver enzyme elevations in the phase 1 studies is unclear.

Several other BACE1 inhibitors have advanced to human clinical trials (Yan and Vassar, 2014) and the clinical safety of longterm BACE1 inhibition remains to be established. The initial impression of a relatively benign phenotype for the original BACE1 KO (Cai et al., 2001; Luo et al., 2001; Roberds et al., 2001) has been eroded the last few years by a steady stream of new phenotypic abnormalities, including hypomyelination (Hu et al., 2006; Willem et al., 2006), axon guidance defects (Rajapaksha et al., 2011; Cao et al., 2012, Hitt et al., 2012), and muscle spindle reduction (Cheret et al., 2013), as reviewed in Yan and Vassar (2014). Many of these are judged to be more developmental processes and linked to a complete KO of BACE1 and whether partial inhibition of BACE1 in elderly patients would elicit similar changes is not clear. Nonetheless, these observations in BACE1 $\mathrm{KO}$ mice provide guidance for monitoring potential AEs in longterm clinical trials for BACE1 inhibitors in AD.

Many, if not all, of the current BACE1 inhibitors in development are thought to be relatively nonselective for BACE1 versus BACE2. The high homology of the active sites of BACE1 and BACE2 makes designing selectivity for BACE1 a considerable challenge. This challenge to medicinal chemists has been heightened recently by the emergence of studies describing functions for BACE2. In particular, mice with a genetic KO of BACE2 express a silver hair color instead of black and this phenotype has been ascribed to altered processing of pigment-cell-specific melanocyte protein, a newly discovered BACE2 substrate (Rochin et al., 2013). Transmembrane protein 27 (TMEM27) is another newly discovered BACE2 substrate that is highly expressed in the pancreas (Esterházy et al., 2011) and has been suggested to play a role in supporting pancreatic $\beta$-cell mass. As with BACE1, other substrates for BACE2 may emerge, but for now, the functional implication for the lack of selectivity against BACE1 and BACE2, other than a potential risk of hypopigmentation, is something the field is carrying forward.

Since its initial cloning in 1999, BACE1 has been a prime drug discovery target for industry and academia. Overcoming a myriad of challenges in "drugging," this target had delayed development of potent BACE1 inhibitors, but several BACE1 inhibitors have now progressed into the clinical setting. Despite the setbacks from unanticipated nonclinical toxicology and clinical AEs experienced with LY2811376 and LY2886721, respectively, which led to the eventual termination of these molecules, the promise of BACE1 inhibitors to test the amyloid hypothesis remains strong. As the field moves toward earlier treatment of individuals with preclinical disease, targeting a protease such as BACE1, which resides at the top of the amyloid cascade, remains a compelling approach. Supporting genetic data from rare mutations in APP that alter BACE1 processing, as exemplified by the A673T APP polymorphism (Jonsson et al., 2012), suggest that relatively modest but sustained inhibition of BACE1 could be an effective strategy for delaying disease progression. The field eagerly awaits this ultimate test of the amyloid hypothesis. 


\section{References}

Cai H, Wang Y, McCarthy D, Wen H, Borchelt DR, Price DL, Wong PC (2001) BACE1 is the major beta-secretase for generation of Abeta peptides by neurons. Nat Neurosci 4:233-234. CrossRef Medline

Cao L, Rickenbacher GT, Rodriguez S. Moulia TW, Albers MW (2012) The precision of axon targeting of mouse olfactory sensory neurons requires the BACE1 protease. Sci Rep 2:231. CrossRef Medline

Cheret C, Willem M, Fricker FR, Wende H, Wulf-Goldenberg A, Tahirovic S, Nave KA, Saftig P, Haass C, Garratt AN, Bennett DL, Birchmeier C (2013) Bacel and Neuregulin-1 cooperate to control formation and maintenance of muscle spindles. EMBO J 32:2015-2028. CrossRef Medline

Dovey HF, John V, Anderson JP, Chen LZ, de Saint Andrieu P, Fang LY, Freedman SB, Folmer B, Goldbach E, Holsztynska EJ, Hu KL, JohnsonWood KL, Kennedy SL, Kholodenko D, Knops JE, Latimer LH, Lee M, Liao Z, Lieberburg IM, Motter RN, et al. (2001) Functional gammasecretase inhibitors reduce beta-amyloid peptide levels in brain. J Neurochem 76:173-181. Medline

Esterházy D, Stützer I, Wang H, Rechsteiner MP, Beauchamp J, Döbeli H, Hilpert H, Matile H, Prummer M, Schmidt A, Lieske N, Boehm B, Marselli L, Bosco D, Kerr-Conte J, Aebersold R, Spinas GA, Moch H, Migliorini C, Stoffel M (2011) Bace2 is a $\beta$ cell-enriched protease that regulates pancreatic $\beta$ cell function and mass. Cell Metab 14:365-377. CrossRef Medline

Games D, Adams D, Alessandrini R, Barbour R, Berthelette P, Blackwell C, Carr T, Clemens J, Donaldson T, Gillespie F (1995) Alzheimer-type neuropathology in transgenic mice overexpressing V717F $\beta$-amyloid precursor protein. Nature 373:523-527. CrossRef Medline

Hitt B, Riordan SM, Kukreja L, Eimer WA, Rajapaksha TW, Vassar R (2012) $\beta$-site amyloid precursor protein (APP)-cleaving enzyme 1 (BACE1)deficient mice exhibit a close homolog of L1 (CHL1) loss-of-function phenotype involving axon guidance defects. J Biol Chem 287:3840838425. CrossRef Medline

Hong L, Koelsch G, Lin X, Wu S, Terzyan S, Ghosh AK, Zhang XC, Tang J (2000) Structure of the protease domain of memapsin 2 (beta-secretase) complexed with inhibitor. Science 290:150-153. CrossRef Medline

Hu X, Hicks CW, He W, Wong P, Macklin WB, Trapp BD, Yan R (2006) Bacel modulates myelination in the central and peripheral nervous system. Nat Neurosci 9:1520-1525. CrossRef Medline

Hussain I, Powell D, Howlett DR, Tew DG, Meek TD, Chapman C, Gloger IS, Murphy KE, Southan CD, Ryan DM, Smith TS, Simmons DL, Walsh FS, Dingwall C, Christie G (1999) Identification of a novel aspartic protease (Asp 2) as beta-secretase. Mol Cell Neurosci 14:419-427. CrossRef Medline

Jonsson T, Atwal JK, Steinberg S, Snaedal J, Jonsson PV, Bjornsson S, Stefansson H, Sulem P, Gudbjartsson D, Maloney J, Hoyte K, Gustafson A, Liu Y, Lu Y, Bhangale T, Graham RR, Huttenlocher J, Bhangale T, Graham RR, Huttenlocher J, et al. (2012) A mutation in APP protects against Alzheimer's disease and age-related cognitive decline. Nature 488:96-99. CrossRef Medline

Lachno DR, Emerson JK, Vanderstichele H, Gonzales C, Martényi F, Konrad RJ, Talbot JA, Lowe SL, Oefinger PE, Dean RA (2012) Validation of a multiplex assay for simultaneous quantification of amyloid-beta peptide species in human plasma with utility for measurements in studies of Alzheimer's disease therapeutics. J Alzheimers Dis 32:905-918. CrossRef Medline

Lin X, Koelsch G, Wu S, Downs D, Dashti A, Tang J (2000) Human aspartic protease memapsin 2 cleaves the beta-secretase site of beta-amyloid precursor protein. Proc Natl Acad Sci U S A 97:1456-1460. CrossRef Medline

Luo Y, Bolon B, Kahn S, Bennett BD, Babu-Khan S, Denis P, Fan W, Kha H, Zhang J, Gong Y, Martin L, Louis JC, Yan Q, Richards WG, Citron M, Vassar R (2001) Mice deficient in BACE1, the Alzheimer's betasecretase, have normal phenotype and abolished beta-amyloid generation. Nat Neurosci 4:231-232. CrossRef Medline

May PC, Dean RA, Lowe SL, Martényi F, Sheehan SM, Boggs LN, Monk SA,
Mathes BM, Mergott DJ, Watson MB, Stout SL, Timm DE, LaBell ES, Gonzales CR, Nakano M, Jhee SS, Yen M, Ereshefsky L, Lindstrom TD, Calligaro DO, et al. (2011) Robust central reduction of amyloid-beta in humans with an orally available, non-peptidic beta-secretase inhibitor. J Neurosci 31:16507-16516. CrossRef Medline

Mullan M, Crawford F, Axelman K, Houlden H, Lilius L, Winblad B, Lannfelt L (1992) A pathogenic mutation for probable Alzheimer's disease in the APP gene at the N-terminums of beta-amyloid. Nat Genet 1:345-347. CrossRef Medline

Murshudov GN, Vagin AA, Dodson EJ (1997) Refinement of macromolecular structures by the maximum-likelihood method. Acta Crystallogr D Biol Crystallogr 53:240-255. CrossRef Medline

Rajapaksha TW, Eimer WA, Bozza TC, Vassar R (2011) The Alzheimer's $\beta$-secretase enzyme BACE1 is required for accurate axon guidance of olfactory sensory neurons and normal glomerulus formation in the olfactory bulb. Mol Neurodegener 6:88. CrossRef Medline

Roberds SL, Anderson J, Basi G, Bienkowski MJ, Branstetter DG, Chen KS, Freedman SB, Frigon NL, Games D, Hu K, Johnson-Wood K, Kappenman KE, Kawabe TT, Kola I, Kuehn R, Lee M, Liu W, Motter R, Nichols NF, Power M, et al. (2001) BACE knockout mice are healthy despite lacking the primary beta-secretase activity in brain: implications for Alzheimer's disease therapeutics. Hum Mol Genet 10:1317-1324. CrossRef Medline

Rochin L, Hurbain I, Serneels L, Fort C, Watt B, Leblanc P, Marks MS, De Strooper B, Raposo G, van Niel G (2013) BACE2 processes PMEL to form the melanosome amyloid matrix in pigment cells. Proc Natl Acad Sci U S A 110:10658-10663. CrossRef Medline

Sinha S, Anderson JP, Barbour R, Basi GS, Caccavello R, Davis D, Doan M, Dovey HF, Frigon N, Hong J, Jacobson-Croak K, Jewett N, Keim P, Knops J, Lieberburg I, Power M, Tan H, Tatsuno G, Tung J, Schenk D, et al. (1999) Purification and cloning of amyloid precursor protein beta secretase from human brain. Nature 402:537-540. CrossRef Medline

Vassar R, Bennett BD, Babu-Khan S, Kahn S, Mendiaz EA, Denis P, Teplow DB, Ross S, Amarante P, Loeloff R, Luo Y, Fisher S, Fuller J, Edenson S, Lile J, Jarosinski MA, Biere AL, Curran E, Burgess T, Louis JC, et al. (1999) Beta-secretase cleavage of Alzheimer's amyloid precursor protein by the transmembrane aspartic protease BACE. Science 286:735-741. CrossRef Medline

Vassar R, Kuhn PH, Haass C, Kennedy ME, Rajendran L, Wong PC, Lichtenthaler SF (2014) Function, therapeutic potential and cell biology of BACE proteases: current status and future prospects. J Neurochem 130: 4-28. CrossRef Medline

Willem M, Garratt AN, Novak B, Citron M, Kaufmann S, Rittger A, DeStrooper B, Saftig P, Birchmeier C, Haass C (2006) Control of peripheral nerve myelination by the $\beta$-secretase BACE1. Science 314:664666. CrossRef Medline

Winn MD, Ballard CC, Cowtan KD, Dodson EJ, Emsley P, Evans PR, Keegan RM, Krissinel EB, Leslie AG, McCoy A, McNicholas SJ, Murshudov GN, Pannu NS, Potterton EA, Powell HR, Read RJ, Vagin A, Wilson KS (2011) Overview of the CCP4 suite and current developments. Acta Crystallogr D Biol Crystallogr 67:235-242. CrossRef Medline

Yan R, Vassar R (2014) Targeting the $\beta$ secretase BACE1 for Alzheimer's disease therapy. Lancet Neurol 13:319-329. CrossRef Medline

Yan R, Bienkowski MJ, Shuck ME, Miao H, Tory MC, Pauley AM, Brashier JR, Stratman NC, Mathews WR, Buhl AE, Carter DB, Tomasselli AG, Parodi LA, Heinrikson RL, Gurney ME (1999) Membrane-anchored as aspartyl protease with Alzheimer's disease beta-secretase activity. Nature 402:533-537. CrossRef Medline

Zamek-Gliszczynski MJ, Ruterbories KJ, Ajamie RT, Wickremsinhe ER, Pothuri L, Rao MV, Basavanakatti VN, Pinjari J, Ramanathan VK, Chaudhary AK (2011) Validation of 96-well equilibrium dialysis with non-radiolabeled drug for definitive measurement of protein binding and application to clinical development of highly-bound drugs. J Pharm Sci 100:2498-2507. CrossRef Medline 